\title{
Profiling of Aroma Compounds Released from Cooking Dendrocalamus latiflorus Shoots
}

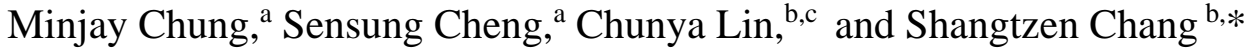 \\ Volatile aroma compounds in Dendrocalamus latiflorus shoots were \\ extracted using solid-phase microextraction (SPME) and then heated at \\ various temperatures and for various durations. Gas chromatography- \\ mass spectrometry (GC-MS) analyses showed that frozen $D$. latiflorus \\ shoots at ambient temperature contain 18 volatile aroma compounds, with \\ limonene and 2-pentyl furan being the major components. Limonene has \\ the fragrance of lemon and citrus fruits, while 2-pentyl furan gives off the \\ scent of flowers and fruits. Additionally, heating temperature had a \\ significant influence on the volatile aroma compounds. Some, including \\ limonene, 2-pentyl furan and $n$-hexanal, showed marked decrement in \\ content and vaporized almost completely at $100^{\circ} \mathrm{C}$, while others, including \\ $n$-heneicosane and 4-hydroxybenzaldehyde, showed pronounced \\ increase in relative contents. Furthermore, there was a positive \\ relationship between $n$-heneicosane content and heating duration but a \\ negative relationship between 4-hydroxybenzaldehyde content and \\ heating duration, revealing substantial effects of heating duration on the \\ volatile aroma compounds of $D$. latiflorus shoots.
}

Keywords: Bamboo shoots; Dendrocalamus latiflorus; Aroma compounds; Solid-phase microextraction (SPME); Gas chromatography-mass spectrometry (GC-MS)

Contact information: a: Experimental Forest, National Taiwan University, No. 12, Section 1, Chien-Shan Road, Chu-Shan, Nantou Hsien, 55750, Taiwan; b: School of Forestry and Resource Conservation, National Taiwan University, Taipei 10617, Taiwan; c: Department of Wood Based Materials and Design, National Chiayi University, Chiayi City 60004, Taiwan; *Corresponding author: peter@ntu.edu.tw

\section{INTRODUCTION}

Bamboo is an important forest resource of high economic value (Liese 1987). Bamboo shoot, which is the budding sprout wrapped inside its sheath (Lu 2001), is often used in Oriental cuisines. Asians have a long history and preference for eating bamboo shoot because of its crispy texture and delicious taste in addition to its high dietary fiber, low fat, and rich mineral content. In Taiwan, there are many different bamboo species cultivated, including Dendrocalamus latiflorus Munro, Phyllostachys pubescens Mazel, $P$. makinoi Hayata, Leleba oldhamii Nakai, and L. edulis Odashimo (Huang et al. 2016). These bamboo species have been used in local cuisines according to their distinctive smell, taste, and texture (Tsai 2002). Of the above-mentioned species, D. latiflorus, L. oldhamii, and L. edulis shoots constitute the main income of bamboo farmers. In Taiwan and Chinese Mainland, D. latiflorus shoots are a popular summer food. D. latiflorus shoots are consumed fresh as well as dried, processed, and canned for exports. Satya et al. (2010) reported Japan's high annual demand for bamboo shoots, importing thousands of tons of fresh and processed $P$. pubescens shoots from Taiwan. The high economic value of bamboo shoots for dietary consumption warrants more attention (Luo 2009). 
Previous studies on bamboo shoots have focused on their nutritional value and nutrient contents, which include carbohydrates, protein, vitamins, and various amino acids and trace elements (Chen et al. 1999; Kumbhare and Bhargava 2007; Nirmala et al. 2007; 2008, Satya et al. 2010). Recent studies have emphasized bamboo shoot's beneficial effects on health. D. latiflorus possesses an antifungal protein, known as dendrocinin or dendrocin, which is a natural source for producing phenolic antioxidants (Wang and Ng 2003; Park and Jhon 2010). Moreover, unsaturated fatty acids and phytosterol in bamboo shoots contribute to reduced serum cholesterol, restrained inflammation, and they help to prevent prostate diseases (Lu et al. 2011). The aroma-active components in fermented bamboo shoots have also been studied (Fu et al. 2002). Profiling volatile compounds of $P$. pubescens shoots showed that spring $P$. pubescens shoots at ambient temperature contain epi-cedrol and methyl salicylate, which have protective properties against insects, while winter $P$. pubescens shoots contain 1-octen-3-ol with a characteristic mushroom smell. A 60 -min heat treatment at $100{ }^{\circ} \mathrm{C}$ revealed $n$-heneicosane as the major compound in winter P. pubescens shoots (Chung et al. 2012).

Current approaches to the extraction of volatile organic compounds and essential oils are numerous and diverse, and the most widely used method is solid-phase microextraction (SPME) (Yang and Peppard 1994; Hsu et al. 2006; Chung et al. 2008). When applying SPME, a fiber coating is employed to extract both volatile and non-volatile components from different media in the liquid or gas phase. Without the need for solvents, SPME is simple and inexpensive (Alexandra and Pawliszyn 1996; Chen et al. 2010; Chung et al. 2012). Considering its ease of implementation and wide application, this study used SPME to extract volatile aroma components from D. latiflorus shoots. Gas chromatography-mass spectrometry (GC-MS) was employed to determine the volatile compounds at ambient temperature. This is the first investigation on the effects of heating temperatures and durations on volatile aroma compounds in D. latiflorus shoots. Findings on the characteristics of $D$. latiflorus shoots would enhance understanding of its aroma compounds released from cooking and promote its use in cuisines.

\section{EXPERIMENTAL}

\section{Materials}

Shoots of ma bamboo (Dendrocalamus latiflorus Munro) were obtained from the Experimental Forest of National Taiwan University located in Shuili. Harvested in July of 2018, the bamboo shoot samples had base diameters ranging from 15 to $20 \mathrm{~cm}$ and were grown to a height of 45 to $60 \mathrm{~cm}$ above the ground. Prior to analysis, the freshly harvested bamboo shoots were first washed and then stored in a sealed bag at $-80{ }^{\circ} \mathrm{C}$ without exposure to light.

\section{Methods}

Treatment conditions

To examine how heating temperatures and durations affect compositional changes and relative contents of aroma constituents, volatile compounds present in D. latiflorus shoots were extracted using SPME at an ambient temperature $\left(25^{\circ} \mathrm{C}\right)$, then steam-cooked at $40{ }^{\circ} \mathrm{C}, 60^{\circ} \mathrm{C}$, and $100^{\circ} \mathrm{C}$. Steam cooking at $100{ }^{\circ} \mathrm{C}$ was conducted for $5 \mathrm{~min}, 30 \mathrm{~min}$, and $60 \mathrm{~min}$. 
Extraction of volatile compounds by SPME

A manual SPME device (Supelco Co., Bellefonte, PA, USA) was used with a 65$\mu \mathrm{m}$ polydimethylsiloxane-divinylbenzene (PDMS/DVB) fiber. The PDMS/DVB fiber was conditioned as recommended by the manufacturer prior to extraction. Frozen $D$. latiflorus shoots, $3 \mathrm{~g}$ in weight, were placed in a $20 \mathrm{~mL}$ vial closed by a PTFE/silicone septum, and then heated in water baths of $25^{\circ} \mathrm{C}, 40{ }^{\circ} \mathrm{C}, 60{ }^{\circ} \mathrm{C}$, and $100{ }^{\circ} \mathrm{C}$ for $30 \mathrm{~min}$. Each extraction was held for $30 \mathrm{~min}$ at different temperatures, followed by 5 -min desorption at a gas chromatography (GC) inlet at $230^{\circ} \mathrm{C}$. Similarly, the samples were steam-cooked at $100{ }^{\circ} \mathrm{C}$ for various durations before SPME extraction for further analysis.

\section{GC-mass spectroscopy (MS) and GC-FID analyses}

An analysis of volatile compounds present in D. latiflorus shoots was conducted using a Trace GC PoLaris Q mass (ion source temperature $230{ }^{\circ} \mathrm{C}, 70 \mathrm{eV}$ ) detector (Thermo Electron Corporation, Waltham, MA, USA) equipped with a DB-5ms capillary column (Crossbond 5\% phenyl methylpolysiloxane with a length of $30 \mathrm{~m}$, diameter of $0.25 \mathrm{~mm}$, and film thickness of $0.25 \mu \mathrm{m}$ ). The oven temperature was held at $40{ }^{\circ} \mathrm{C}$ for $4 \mathrm{~min}$, then programmed to increase from 40 to $230{ }^{\circ} \mathrm{C}$ at a rate of $4{ }^{\circ} \mathrm{C} / \mathrm{min}$ and held for $5 \mathrm{~min}$. Other parameters included an injector temperature at $230{ }^{\circ} \mathrm{C}$; carrier gas, helium at a flow rate of $1 \mathrm{~mL} / \mathrm{min}$; split ratio of 1:30; and a scan range of 50 to $400 \mathrm{amu}$. Each extraction takes about $46.67 \mathrm{~min}$.

The major components of $D$. latiflorus shoots identified were confirmed through comparing against standards and according to their mass spectral fragmentation with reference to the Wiley 7.0 and National Institute of Standards and Technology (NIST) V2.0 (Adams 2007). The percentage peak area was calculated using the GC-FID. In addition, the Kovats index (KI) was also calculated (Eq. 1),

$$
K I=100 N+100 \frac{\log t^{\prime}{ }_{\mathrm{R}(\mathrm{X})}-\log t^{\prime}{ }_{\mathrm{R}(N)}}{\log t^{\prime}{ }_{\mathrm{R}(N+1)}-\log t^{\prime}{ }_{\mathrm{R}(N)}}
$$

where $t^{\prime} \mathrm{R}(N)$ and $t^{\prime} \mathrm{R}(N+1)$ are the adjusted retention times for $N$ and $N+1$ carbon atoms, respectively, in $n$-alkanes, and $t^{\prime} \mathrm{R}(\mathrm{X})$ is the adjusted retention time for an unknown compound $\mathrm{X} ; t^{\prime} \mathrm{R}(\mathrm{X})$ should fall between $t^{\prime} \mathrm{R}(N)$ and $\mathrm{t}^{\prime} \mathrm{R}(N+1)$.

\section{RESULTS AND DISCUSSION}

\section{Volatile Aroma Compounds Present in D. latiflorus Shoots at Ambient Temperature}

Figure 1 shows the GC-MS spectra of volatile aroma compounds present in $D$. latiflorus shoots at ambient temperature, and Table 1 lists their relative contents. At ambient temperature, D. latiflorus shoot is comprised of 18 volatile compounds, categorized under monoterpenes $(35.99 \%)$ and furan $(20.41 \%)$, followed by aliphatic aldehydes $(13.30 \%)$, benzenoids $(9.83 \%)$, and aliphatic alcohols $(4.55 \%)$. The major volatile aroma compounds include limonene $(25.11 \%)$ and 2-pentyl furan $(20.41 \%)$, followed by $n$-hexanal $(9.80 \%), \alpha$-pinene $(6.64 \%)$, and benzaldehyde $(6.14 \%)$. 


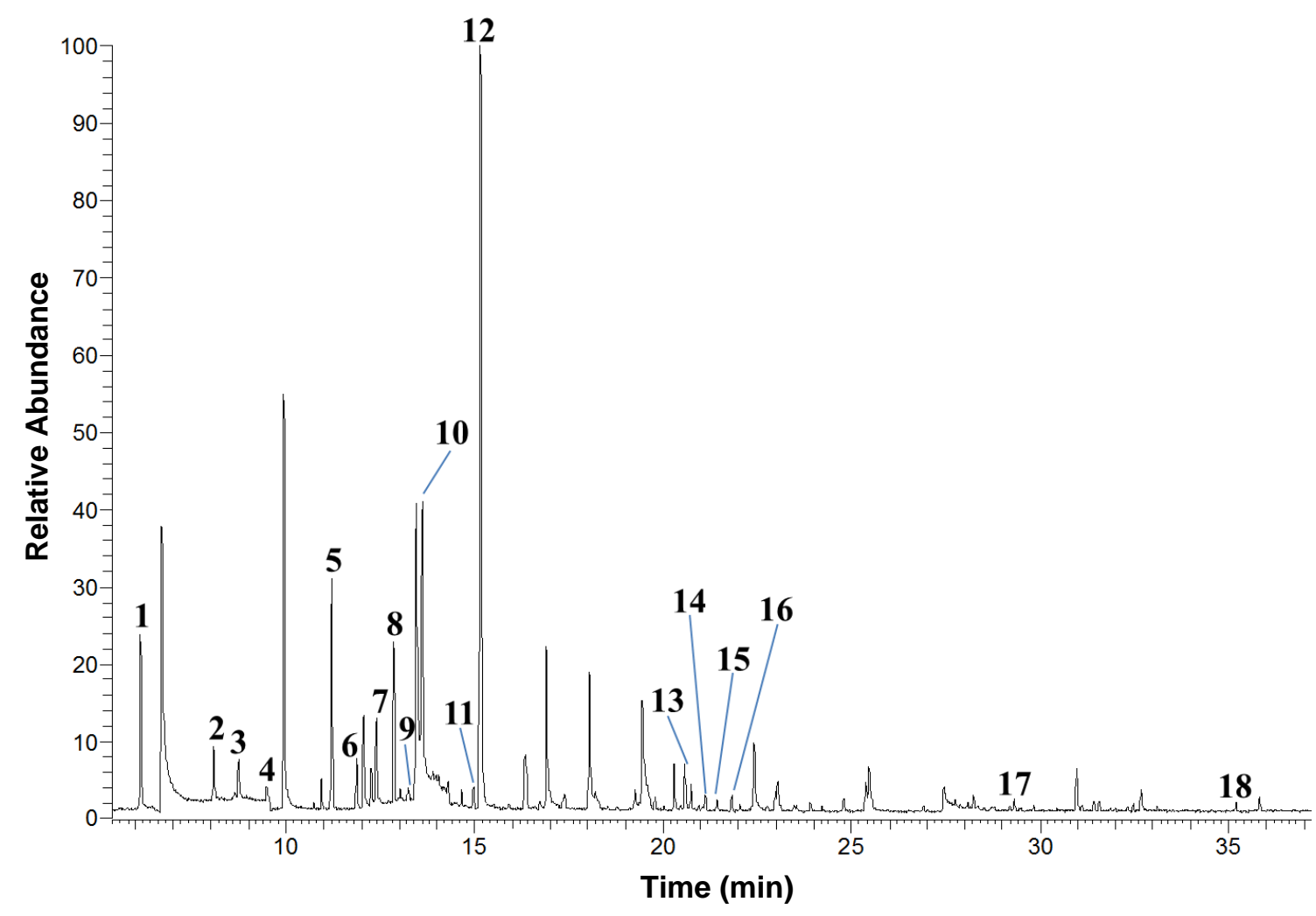

Fig. 1. GC-MS spectra of volatile aroma compounds present in $D$. latiflorus shoots at $25^{\circ} \mathrm{C}$. Peak number: (1) $n$-hexanal; (2) trans-2-hexen-1-al; (3) $n$-hexanol; (4) styrene; (5) $\alpha$-pinene; (6) camphene; (7) benzaldehyde; (8) sabinene; (9) $\beta$-pinene; (10) 2-pentyl furan; (11) p-cymene; (12) limonene; (13) $n$-nonanol; (14) naphthalene; (15) methyl salicylate; (16) $n$-dodecane; (17) trans- $\beta$ caryophyllene; and (18) cedrol.

Table 2 lists the characteristic aroma of the volatile compounds released by $D$. latiflorus shoots at $25{ }^{\circ} \mathrm{C}$ according to the results surveyed from related literature. Limonene and 2-pentyl furan are the main aroma compounds found in D. latiflorus shoots. The former possesses the fresh, fruit-floral fragrance of lemon and citrus characteristics (Tu et al. 2002; Choi 2006; Gürbüz et al. 2006; Costa et al. 2008), while the latter has the scent of flowers and fruits (Yang et al. 2008. Klensporf and Henryk 2008; Thompson et al. 2009; Olivares et al. 2011). Limonene and 2-pentyl furan are often used as aromatic food additives. As for the minor volatile aroma compounds, $n$-hexanal has a grass and herbal fragrance (Gocmen et al. 2004; Klensporf and Henryk 2008; Wang et al. 2008), $\alpha$-pinene gives the scent of pinewood and fresh herbs (Tu et al. 2002; Choi 2006; Costa et al. 2008), and benzaldehyde smells nutty like almond and sweet candy (Gocmen et al. 2004; Costa et al. 2008; Yang et al. 2008).

In addition to being added to food for its aroma, limonene has also been used as a pesticide. Ibrahim et al. (2001) reviewed the suitability of limonene for the control of insect pests and found that not only is it phytotoxic, it also shows insecticidal, repellent, antimicrobial activities, making it a natural ingredient for pesticides. At ambient temperature, $P$. pubescens shoots contain methyl salicylate (Chung et al. 2012). Jayasekara et al. (2002) researched the methanolic extract of Securidaca longepedunculata (Polygalaceae) root bark, commonly used as a pesticide by the Africans, and found methyl salicylate as its principal volatile component. 
Table 1. Relative Contents of Volatile Aroma Compounds Present in D. latiflorus Shoots at $25^{\circ} \mathrm{C}$

\begin{tabular}{|c|c|c|c|c|c|c|}
\hline $\begin{array}{l}\text { R.t. } \\
\text { (min) }\end{array}$ & $\mathrm{KI}^{\mathrm{a}}$ & $r K^{b}$ & Compounds & MF & Relative content $(\%)^{c}$ & Identification $^{d}$ \\
\hline 6.15 & 801 & 801 & $n$-Hexanal & $\mathrm{C}_{6} \mathrm{H}_{12} \mathrm{O}$ & 9.80 & $\mathrm{KI}, \mathrm{MS}, \mathrm{ST}$ \\
\hline 8.07 & 857 & 855 & trans-2-Hexen-1-al & $\mathrm{C}_{6} \mathrm{H}_{10} \mathrm{O}$ & 3.50 & $\mathrm{KI}, \mathrm{MS}$ \\
\hline 8.74 & 874 & 870 & $n$-Hexanol & $\mathrm{C}_{6} \mathrm{H}_{14} \mathrm{O}$ & 2.14 & $\mathrm{KI}, \mathrm{MS}, \mathrm{ST}$ \\
\hline 9.50 & 890 & - & Styrene & $\mathrm{C}_{8} \mathrm{H}_{8}$ & 1.89 & $\mathrm{KI}, \mathrm{MS}, \mathrm{ST}$ \\
\hline 11.21 & 934 & 939 & $\alpha$-Pinene & $\mathrm{C}_{10} \mathrm{H}_{16}$ & 6.64 & $\mathrm{KI}, \mathrm{MS}, \mathrm{ST}$ \\
\hline 11.87 & 951 & 954 & Camphene & $\mathrm{C}_{10} \mathrm{H}_{16}$ & 0.96 & $\mathrm{KI}, \mathrm{MS}, \mathrm{ST}$ \\
\hline 12.40 & 964 & 960 & Benzaldehyde & $\mathrm{C}_{7} \mathrm{H}_{6} \mathrm{O}$ & 6.14 & $\mathrm{KI}, \mathrm{MS}, \mathrm{ST}$ \\
\hline 12.85 & 974 & 975 & Sabinene & $\mathrm{C}_{10} \mathrm{H}_{16}$ & 2.42 & $\mathrm{KI}, \mathrm{MS}, \mathrm{ST}$ \\
\hline 13.02 & 978 & 979 & $\beta$-Pinene & $\mathrm{C}_{10} \mathrm{H}_{16}$ & 0.10 & $\mathrm{KI}, \mathrm{MS}, \mathrm{ST}$ \\
\hline 13.62 & 991 & 988 & 2-Pentyl furan & $\mathrm{C}_{9} \mathrm{H}_{14} \mathrm{O}$ & 20.41 & $\mathrm{KI}, \mathrm{MS}, \mathrm{ST}$ \\
\hline 14.97 & 1025 & 1025 & p-Cymene & $\mathrm{C}_{10} \mathrm{H}_{14}$ & 0.77 & $\mathrm{KI}, \mathrm{MS}, \mathrm{ST}$ \\
\hline 15.21 & 1031 & 1029 & Limonene & $\mathrm{C}_{10} \mathrm{H}_{16}$ & 25.11 & $\mathrm{KI}, \mathrm{MS}, \mathrm{ST}$ \\
\hline 20.59 & 1169 & 1169 & $n$-Nonanol & $\mathrm{C}_{9} \mathrm{H}_{20} \mathrm{O}$ & 2.41 & $\mathrm{KI}, \mathrm{MS}, \mathrm{ST}$ \\
\hline 21.11 & 1182 & 1181 & Naphthalene & $\mathrm{C}_{10} \mathrm{H}_{8}$ & 0.85 & $\mathrm{KI}, \mathrm{MS}, \mathrm{ST}$ \\
\hline 21.42 & 1190 & 1192 & Methyl salicylate & $\mathrm{C}_{8} \mathrm{H}_{8} \mathrm{O}_{3}$ & 0.95 & $\mathrm{KI}, \mathrm{MS}, \mathrm{ST}$ \\
\hline 21.81 & 1199 & 1200 & $n$-Dodecane & $\mathrm{C}_{12} \mathrm{H}_{26}$ & 0.47 & $\mathrm{KI}, \mathrm{MS}, \mathrm{ST}$ \\
\hline 29.32 & 1417 & 1419 & trans- $\beta$-Caryophyllene & $\mathrm{C}_{15} \mathrm{H}_{24}$ & 0.65 & $\mathrm{KI}, \mathrm{MS}, \mathrm{ST}$ \\
\hline 35.21 & 1607 & 1600 & Cedrol & $\mathrm{C}_{15} \mathrm{H}_{26} \mathrm{O}$ & 1.98 & $\mathrm{KI}, \mathrm{MS}, \mathrm{ST}$ \\
\hline \multicolumn{4}{|c|}{ Monoterpenes } & & 35.99 & \\
\hline \multicolumn{4}{|c|}{ n-Alkanes } & & 0.47 & \\
\hline \multicolumn{4}{|c|}{ Sesquiterpenes } & & 0.65 & \\
\hline \multicolumn{4}{|c|}{ Oxygenated sesquiterpenes } & & 1.98 & \\
\hline \multicolumn{4}{|c|}{ Aliphatic alcohols } & & 4.55 & \\
\hline \multicolumn{4}{|c|}{ Aliphatic aldehydes } & & 13.30 & \\
\hline \multicolumn{4}{|c|}{ Benzenoid } & & 9.83 & \\
\hline \multicolumn{4}{|c|}{ Furan } & & 20.41 & \\
\hline \multicolumn{4}{|c|}{ Identified } & & 87.18 & \\
\hline
\end{tabular}

a: Kovats index relative to $\mathrm{C}_{8}-\mathrm{C}_{22} n$-alkanes on the $\mathrm{DB}-5 \mathrm{~ms}$ column

b: Identification based on comparison of the mass spectrum, Kovats index on a DB- $5 \mathrm{~ms}$ column in Adams (2007) and co-injection with authentic compounds

c: Relative content of compound less than $0.1 \%$, was not shown in the table

$\mathrm{d}$ : KI, Kovats index; MS, mass spectroscopy; ST, co-injection with authentic standard compounds 
Table 2. Aroma of Volatile Compounds Present in D. latiflorus Shoots at $25^{\circ} \mathrm{C}$

\begin{tabular}{|c|c|c|c|}
\hline No. & $\begin{array}{l}\text { Volatile } \\
\text { compounds }\end{array}$ & Aroma & References \\
\hline 1 & $n$-Hexanal & Grassy, Green & $\begin{array}{c}\text { Gocmen et al. 2004; Klensporf and } \\
\text { Henryk 2008; Wang et al. } 2008\end{array}$ \\
\hline 2 & $\begin{array}{l}\text { trans-2-Hexen-1- } \\
\text { al } \\
\end{array}$ & Fragrant, Sweet, Fruity & Wang et al. 2008 \\
\hline 3 & $n$-Hexanol & $\begin{array}{c}\text { Cut grass, Sweet, Resinous, } \\
\text { Green }\end{array}$ & Gürbüz et al. 2006; Costa et al. 2008 \\
\hline 4 & Styrene & Plastic, PVC, Solvent & Garruti et al. 2006 \\
\hline 5 & $\alpha$-Pinene & $\begin{array}{l}\text { Resinous, Pine-like, } \\
\text { Herbaceous, Fresh }\end{array}$ & \begin{tabular}{|c} 
Tu et al. 2002; Costa et al. 2008; Choi \\
2006
\end{tabular} \\
\hline 6 & Camphene & Warm, Herbaceous, Green & Tu et al. 2002; Choi 2006 \\
\hline 7 & Benzaldehyde & $\begin{array}{c}\text { Almond, Sweet, Candy, Fruity, } \\
\text { Nutty, Fragrant }\end{array}$ & $\begin{array}{c}\text { Gocmen et al. 2004; Costa et al. } \\
\text { 2008; Wang et al. 2008; Yang et al. } \\
\text { 2008 }\end{array}$ \\
\hline 8 & Sabinene & Green, Spicy, Warm, Woody & $\begin{array}{c}\text { Tu et al. 2002; Choi 2006; Costa et al. } \\
2008\end{array}$ \\
\hline 9 & $\beta$-Pinene & $\begin{array}{c}\text { Fresh, Pine-like, Resinous, } \\
\text { Green, Waxy }\end{array}$ & $\begin{array}{c}\text { Tu et al. 2002; Choi 2006; Costa et al. } \\
2008\end{array}$ \\
\hline 10 & 2-Pentyl furan & $\begin{array}{l}\text { Floral, Fruit, Cucumber, Hay, } \\
\text { Licorice, Fatty (very faint), } \\
\text { Meat broth, Savory, Metallic }\end{array}$ & $\begin{array}{c}\text { Klensporf and Henryk 2008; Yang et } \\
\text { al. 2008; Thompson et al. 2009; } \\
\text { Olivares et al. 2011 }\end{array}$ \\
\hline 11 & $p$-Cymene & Green, Citric & $\begin{array}{l}\text { Tu et al. 2002; Choi 2006; Costa et al. } \\
2008\end{array}$ \\
\hline 12 & Limonene & $\begin{array}{l}\text { Citrus-like, Pungent green, } \\
\text { Lemon-like, Citric, Fresh }\end{array}$ & $\begin{array}{c}\text { Tu et al. 2002; Choi } 2006 \text {; Gürbüz et } \\
\text { al. 2006; Costa et al. } 2008\end{array}$ \\
\hline 14 & Naphthalene & Naphthalene, Old house & Gocmen et al. 2004; Yang et al. 2008 \\
\hline 15 & Methyl salicylate & Sweet, Spicy, Minty & Wang et al. 2008 \\
\hline 16 & $\begin{array}{c}\text { trans- } \beta- \\
\text { Caryophyllene }\end{array}$ & Spicy, Woody & Sant'Anna et al. 2007 \\
\hline 17 & Cedrol & Herbaceous & Tu et al. 2002; Choi 2006 \\
\hline
\end{tabular}

Freshly harvested $D$. latiflorus shoots have fragrances attributable to their two main volatile aroma components, limonene and 2-pentyl furan. In addition, limonene also offers protection against insect and pest attack. Hence, although both $D$. latiflorus shoots and spring $P$. pubescens shoots have high carbohydrate contents and are grown above the ground, their hard sheath and chemical composition, especially limonene, contribute to self-defense against attack from insects and other microorganisms.

\section{Effect of Heating Temperature on Volatile Compounds of $\boldsymbol{D}$. latiflorus Shoots}

Table 3 shows the changes in composition of $D$. latiflorus shoots when heated at different temperatures and lists the changes in relative contents (\%) of its volatile aroma constituents after heat treatment. The contents of monoterpenes, furan, and aliphatic aldehydes decrease from $35.99 \%, 20.41 \%$, and $13.30 \%$ at ambient temperature, to $15.05 \%$, $17.64 \%$, and $3.76 \%$ at $40{ }^{\circ} \mathrm{C}$, and finally to $0.42 \%, 1.43 \%$, and $0.70 \%$ at $100{ }^{\circ} \mathrm{C}$, respectively. Such marked decline in contents evidenced the obvious influence of heating temperature on the composition of $D$. latiflorus shoots. The same trend was observed for limonene, 2-pentyl furan, and $n$-hexanal, which are the major monoterpenoids, furan, and 
aliphatic aldehyde compounds, respectively. Their relative contents dropped markedly from $25.11 \%, 20.41 \%$, and $9.80 \%$ at ambient temperature to $0.42 \%, 1.43 \%$, and $0.41 \%$ at $100{ }^{\circ} \mathrm{C}$, respectively. In other words, these volatile aroma compounds almost vaporized completely. As reported by Ibrahim et al. (2001), while limonene has shown deterrent and insecticidal properties, it is volatile under high temperature, thus accounting for the decline in relative content with an increase in heating temperature. In the analysis conducted by Lehtinen and Laakso (2004) on the quality of oat products, 2-pentyl furan and linoleic acid were produced under lipid oxidation and their relative contents decreased with increasing processing temperature. Apart from these major volatile aroma components, other minor ones also show obvious reductions in relative contents at higher heating temperatures. As shown in Table 3, the relative contents of $\alpha$-pinene and benzaldehyde at ambient temperature were $6.64 \%$ and $6.14 \%$, respectively. At $100{ }^{\circ} \mathrm{C}$, the content of benzaldehyde dropped to $0.16 \%$ while $\alpha$-pinene could no longer be detected, thus revealing the obvious effects of heating temperature on these two aromatic constituents.

Table 3. Changes in Relative Contents (\%) of Volatile Compounds Present in $D$. latiflorus Shoots after Heating at Different Temperatures for $30 \mathrm{~min}$

\begin{tabular}{|c|c|c|c|c|c|c|c|c|}
\hline \multirow{2}{*}{$\begin{array}{l}\text { R.t. } \\
(\min )\end{array}$} & \multirow{2}{*}{$\mathrm{KI}^{\mathrm{a}}$} & \multirow{2}{*}{$\mathrm{rKI}^{\mathrm{b}}$} & \multirow{2}{*}{ Compounds } & \multirow{2}{*}{ MF } & \multicolumn{4}{|c|}{ Heating Temperatures $\left({ }^{\circ} \mathrm{C}\right)$} \\
\hline & & & & & $25^{*}$ & $40^{*}$ & $60^{*}$ & $100^{*}$ \\
\hline 6.13 & 801 & 801 & $n$-Hexanal & $\mathrm{C}_{6} \mathrm{H}_{12} \mathrm{O}$ & 9.80 & 1.31 & 0.69 & 0.41 \\
\hline 11.21 & 934 & 939 & $\alpha$-Pinene & $\mathrm{C}_{10} \mathrm{H}_{16}$ & 6.64 & 1.76 & 1.41 & - \\
\hline 12.41 & 964 & 960 & Benzaldehyde & $\mathrm{C}_{7} \mathrm{H}_{6} \mathrm{O}$ & 6.14 & 5.21 & 1.99 & 0.16 \\
\hline 13.62 & 991 & 988 & 2-Pentyl furan & $\mathrm{C}_{9} \mathrm{H}_{14} \mathrm{O}$ & 20.41 & 17.64 & 6.90 & 1.43 \\
\hline 15.21 & 1031 & 1029 & Limonene & $\mathrm{C}_{10} \mathrm{H}_{16}$ & 25.11 & 11.98 & 4.12 & 0.42 \\
\hline 27.42 & 1360 & 1355 & 4-Hydroxybenzaldehyde & $\mathrm{C}_{7} \mathrm{H}_{6} \mathrm{O}_{2}$ & - & 11.58 & 10.50 & 45.33 \\
\hline 44.12 & 2097 & 2100 & $n$-Heneicosane & $\mathrm{C}_{21} \mathrm{H}_{44}$ & - & 1.18 & 14.64 & 33.45 \\
\hline 45.59 & 2200 & 2200 & $n$-Docosane & $\mathrm{C}_{22} \mathrm{H}_{46}$ & - & - & 0.29 & 2.66 \\
\hline \multicolumn{4}{|c|}{ Monoterpenes } & & 35.99 & 15.05 & 5.53 & 0.42 \\
\hline \multicolumn{4}{|c|}{ n-Alkanes } & & 0.47 & 2.13 & 16.32 & 36.40 \\
\hline \multicolumn{4}{|c|}{ Sesquiterpenes } & & 0.65 & 1.14 & 5.09 & 0.01 \\
\hline \multicolumn{4}{|c|}{ Oxygenated sesquiterpenes } & & 1.98 & 1.25 & 2.10 & 0.16 \\
\hline \multicolumn{4}{|c|}{ Aliphatic alcohols } & & 4.55 & 10.50 & 10.46 & 0.36 \\
\hline \multicolumn{4}{|c|}{ Aliphatic aldehydes } & & 13.30 & 3.76 & 1.94 & 0.70 \\
\hline \multicolumn{4}{|c|}{ Benzenoids } & & 9.83 & 18.79 & 17.17 & 45.80 \\
\hline \multicolumn{4}{|c|}{ Furan } & & 20.41 & 17.64 & 6.90 & 1.43 \\
\hline \multicolumn{4}{|c|}{ Identified } & & 87.18 & 70.27 & 65.50 & 84.86 \\
\hline
\end{tabular}

a: Kovats index relative to $\mathrm{C}_{8}-\mathrm{C}_{22} n$-alkanes on the $\mathrm{DB}-5 \mathrm{~ms}$ column

b: Identification based on comparison of the mass spectrum, Kovats index on a DB-5ms column in Adams (2007) and co-injection with authentic compounds

${ }^{*}$ Relative content of compound less than $0.1 \%$, was not shown in the table 
In contrast, some volatile compounds of D. latiflorus shoots increased in content with higher heating temperatures (Chung et al. 2012). As seen in Table 3, $n$-alkanes showed the most obvious increase, from a trace amount of $0.47 \%$ at ambient temperature, to $2.13 \%$ at $40{ }^{\circ} \mathrm{C}, 16.32 \%$ at $60{ }^{\circ} \mathrm{C}$, and $36.40 \%$ at $100{ }^{\circ} \mathrm{C}$. The same trend was observed for $n$ heneicosane, the major constituent of $n$-alkane, which was hardly detectable at ambient temperature but became the second major component $(33.45 \%)$ after being heated at 100 ${ }^{\circ} \mathrm{C}$. Similarly, the relative content of benzenoid, as shown in Table 3, also increased markedly from $9.83 \%$ at ambient temperature to $45.80 \%$ at $100{ }^{\circ} \mathrm{C}$. Its major constituents, $n$-heneicosane and 4-hydroxybenzaldehyde, also showed comparable increases in relative contents, as can be seen in Table 3, from barely detectable at ambient temperature to $33.45 \%$ and $45.33 \%$, respectively, at $100{ }^{\circ} \mathrm{C}$. Similar findings were obtained for spring and winter $P$. pubescens shoots when heated at $100{ }^{\circ} \mathrm{C}$ with $n$-heneicosane becoming the major constituent (Chung et al. 2012).

When assessing the antidepressant effect of water extract of Gastrodia elata B1, Chen et al. (2008) found that 4-hydroxybenzaldehyde is one of the main constituents of monoamine oxidase (MAO) inhibitors. Kaunzinger et al. (1997) detected 4hydroxybenzaldehyde of considerably higher proportion than any vanilla extract. Ha et al. (2000) also found evidence in rat brains that antioxidation and GABAergic neuromodulation of 4-hydroxybenzaldehyde partially contribute to an antiepileptic and anticonvulsive activity of $G$. elata B1.

\section{Effect of Heating Duration on Volatile Compounds of D. latiflorus Shoot}

Table 4 shows the changes in composition of D. latiflorus shoots heated at $100{ }^{\circ} \mathrm{C}$ for different durations. The $n$-alkanes and benzenoids showed opposite changes in relative content with heating duration. The relative content of $n$-alkanes increased with heating duration, from $35.84 \%$ after $5 \mathrm{~min}$, to $36.40 \%$ after $30 \mathrm{~min}$, finally reaching $43.39 \%$ after $60 \mathrm{~min}$, while the relative content of benzenoids decreased with heating duration, from $54.30 \%$ after $5 \mathrm{~min}$, to $45.80 \%$ after $30 \mathrm{~min}$, and finally reaching $35.24 \%$ after $60 \mathrm{~min}$. In other words, there exists a positive (negative) relationship between the relative content of $n$-alkanes (benzenoids) with heating duration. Such trends can be accounted for by the changes in the relative content of volatile compounds present in D. latiflorus shoots, shown in Table 3.

As mentioned above, $n$-alkanes comprise mainly $n$-heneicosane, whose relative content increases from $33.07 \%$ after $5 \mathrm{~min}$, to $33.45 \%$ after $30 \mathrm{~min}$, and ultimately reaching $39.54 \%$ after $60 \mathrm{~min}$, as can be seen in Table 4. This positive relationship between $n$ heneicosane content and heating duration in D. latiflorus shoots echoes the results obtained by Chung et al. (2012) for winter P. pubescens shoots. On the other hand, benzenoids are mainly comprised of 4-hydroxybenzaldehyde, whose relative content decreases from $53.89 \%$ after $5 \mathrm{~min}$, to $45.33 \%$ after $30 \mathrm{~min}$, finally reaching $34.64 \%$ after $60 \mathrm{~min}$, as can be seen in Table 4. This negative relationship between 4-hydroxybenzaldehyde content and heating duration in $D$. latiflorus shoots is also consistent with the findings obtained by Chung et al. (2012) for spring P. pubescens shoots. Other minor fatty acid and ester compounds, including dodecanoic acid, methyl linoleate, and linoleic acid, also showed increases in relative content with prolonged heating duration, implying a positive relationship of fatty acid and ester compounds in $D$. latiflorus shoots with heating duration. 
Table 4. Changes in Relative Contents of Volatile Compounds Present in $D$. latiflorus Shoots Heated at $100{ }^{\circ} \mathrm{C}$ for Different Durations

\begin{tabular}{|c|c|c|c|c|c|c|c|}
\hline \multirow{2}{*}{$\begin{array}{l}\text { R.t. } \\
\text { (min) }\end{array}$} & \multirow{2}{*}{$\mathrm{KI}^{\mathrm{a}}$} & \multirow{2}{*}{$\mathrm{rKI}^{\mathrm{b}}$} & \multirow{2}{*}{ Compounds } & \multirow{2}{*}{ MF } & \multicolumn{3}{|c|}{ Duration time (min) } \\
\hline & & & & & $5^{\star}$ & $30^{*}$ & $60^{*}$ \\
\hline 27.42 & 1360 & 1355 & 4-Hydroxybenzaldehyde & $\mathrm{C}_{7} \mathrm{H}_{6} \mathrm{O}$ & 53.89 & 45.33 & 34.64 \\
\hline 33.83 & 1562 & 1569 & Dodecanoic acid & $\mathrm{C}_{13} \mathrm{H}_{26} \mathrm{O}_{2}$ & 0.93 & 1.16 & 1.41 \\
\hline 44.01 & 2088 & 2091 & Methyl linoleate & $\mathrm{C}_{19} \mathrm{H}_{34} \mathrm{O}_{2}$ & 0.38 & 2.37 & 2.14 \\
\hline 44.12 & 2097 & 2100 & $n$-Heneicosane & $\mathrm{C}_{21} \mathrm{H}_{44}$ & 33.07 & 33.45 & 39.54 \\
\hline 44.52 & 2125 & 2129 & Linoleic acid & $\mathrm{C}_{18} \mathrm{H}_{32} \mathrm{O}_{2}$ & 0.45 & 5.58 & 8.78 \\
\hline 45.59 & 2200 & 2200 & n-Docosane & $\mathrm{C}_{22} \mathrm{H}_{46}$ & 2.26 & 2.66 & 3.37 \\
\hline \multicolumn{4}{|c|}{ Monoterpenes $^{c}$} & & 0.40 & 0.42 & 0.40 \\
\hline \multicolumn{4}{|c|}{ n-Alkanes } & & 35.84 & 36.40 & 43.39 \\
\hline \multicolumn{4}{|c|}{ Fatty acids \& esters } & & 1.76 & 9.12 & 12.34 \\
\hline \multicolumn{4}{|c|}{ Sesquiterpenes $^{c}$} & & 0.05 & 0.01 & 0.04 \\
\hline \multicolumn{4}{|c|}{ Oxygenated sesquiterpenes } & & 0.16 & 0.16 & 0.15 \\
\hline \multicolumn{4}{|c|}{ Aliphatic alcohols } & & 0.56 & 0.36 & 0.53 \\
\hline \multicolumn{4}{|c|}{ Aliphatic aldehydes } & & 0.66 & 0.70 & 0.76 \\
\hline \multicolumn{4}{|c|}{ Benzenoids } & & 54.30 & 45.80 & 35.24 \\
\hline \multicolumn{4}{|c|}{ Furan } & & 0.75 & 1.43 & 1.73 \\
\hline \multicolumn{4}{|c|}{ Identified } & & 94.48 & 94.40 & 94.58 \\
\hline
\end{tabular}

a: Kovats index relative to $\mathrm{C}_{8}-\mathrm{C}_{22} n$-alkanes on the $\mathrm{DB}-5 \mathrm{~ms}$ column

b: Identification based on comparison of the mass spectrum, Kovats index on a DB- $5 \mathrm{~ms}$ column in Adams (2007) and co-injection with authentic compounds

${ }^{*}$ Relative content of compound less than $0.1 \%$ was not shown in the table

\section{CONCLUSIONS}

1. The effects of heating temperature and duration on the volatile compounds of $D$. latiflorus shoots were examined. Extraction using SPME followed by GC-MS analyses showed that frozen $D$. latiflorus shoots at ambient temperature contain 18 volatile compounds, with limonene and 2-pentyl furan constituting the majority.

2. Limonene has the aroma of lemon and citrus fruits, while 2-pentyl furan is redolent of flowers and fruits. Moreover, heating temperature was found to have an obvious impact on the volatile aroma compounds.

3. Limonene, 2-pentyl furan, and $n$-hexanal, showed a marked decline in content and became almost vaporized completely at $100{ }^{\circ} \mathrm{C}$, while others compounds, including $n$ heneicosane and 4-hydroxybenzaldehyde, showed a pronounced increase in relative contents.

4. There existed a positive relationship between $n$-heneicosane content and heating duration but a negative relationship between 4-hydroxybenzaldehyde content and heating duration, revealing the substantial effects of heating duration on volatile aroma compounds of $D$. latiflorus shoots. 


\section{ACKNOWLEDGMENTS}

The authors acknowledge the financial support from the Experimental Forest, College of Bioresource and Agriculture, National Taiwan University, Taiwan under grant (109-C02), and from the Forestry Bureau, Taiwan.

\section{REFERENCES CITED}

Adams, R. P. (2007). Identification of Essential Oil Components by Gas Chromatography and Mass Spectroscopy, Allured Publishing Corporation, Carol Stream, IL, USA.

Alexandra, S., and Pawliszyn, J. (1996). "Analysis of flavor volatiles using headspace solid-phase microextraction," Journal of Agriculture and Food Chemistry 44(8), 2187-2193. DOI: 10.1021/jf950727k

Chen, Y. J., Cheng, S. S., and Chang, S. T. (2010). "Monitoring the emission of volatile organic compounds from the leaves of Calocedrus macrolepis var. formosana using solid-phase micro-extraction," Journal of Wood Science 56(2), 140-147. DOI: 10.1007/s10086-009-1071-z

Chen, P. J., Hsieh, C. L., Su, K. P., Hou, Y. C. Chiang, H. M., Lin, I. H., and Sheen, L. Y. (2008). "The antidepressant effect of Gastrodia elata Bl. on the forced-swimming test in rats," The American Journal of Chinese Medicine 36(1), 95-106. DOI: 10.1142/S0192415X08005618

Chen, C. J., Qiu, E. F., Huang, R. Z., Fan, H. H., and Jiang, J. X. (1999). "Study on the spring shoot nutrient content of Phyllostachys pubescens of different provenances. (in Chinese)," Journal of Bamboo Research 18(1), 6-10.

Costa, R., Zellner, B. d., Crupi, M. L., De Fina, M. R., Valentino, M. R., Dugo, P., Dugo, G., and Mondello, L. (2008). "GC-MS, GC-O and enantio-GC investigation of the essential oil of Tarchonanthus camphoratus L," Flavour and Fragrance Journal 23(1), 40-48. DOI: 10.1002/ffj.1854

Chung, M. J., Cheng, S. S., and Chang, S. T. (2008). "Effects of four extraction methods on the constituents of essential oils from the leaves of Clausena excavate (in Chinese)," Forest Products Industries 27(4), 271-280.

Chung, M. J., Cheng, S. S., Lin, C. Y., and Chang, S. T. (2012). "Profiling of volatile compounds of Phyllostachys pubescens shoots in Taiwan," Food Chemistry 134(4), 1732-1737. DOI: 10.1016/j.foodchem.2012.03.120

Choi, H. S. (2006). "Headspace analyses of fresh leaves and stems of Angelica gigas Nakai, a Korean medicinal herb," Flavour and Fragrance Journal 21(4), 604-608. DOI: $10.1002 /$ ffj. 1602.

Council of Agriculture Forest Service (2000). Taiwan Forestry Statistics. Copyright by Council of Agriculture Forest Service, Taiwan [In Chinese].

$\mathrm{Fu}$, S. G., Yoon, Y., and Bazemore, R. (2002). "Aroma-active components in fermented bamboo shoots," Journal of Agriculture and Food Chemistry 50(3), 549-554. DOI: 10.1021/jf010883t

Garruti, D. S., Maria, R. B., Franco, Silva, M. A., Janzantti, N. S., and Alves, G. L. (2006). "Assessment of aroma impact compounds in a cashew apple-based alcoholic beverage by GC-MS and GC-olfactometry," LWT- Food Science and Technology 39(4), 373-378. DOI: 10.1016/j.lwt.2005.02.006 
Gocmen, D., Gurbuz, O., Rouseff, R. L., Smoot, J. M., and Dagdelen, A. F. (2004). “Gas chromatographic-olfactometric characterization of aroma active compounds in sundried and vacuum-dried tarhana," European Food Research and Technology 218, 513-578. DOI: 10.1007/s00217-004-0913-6

Gürbüz, O., Rouseff, J. M., and Rouseff, R. L. (2006). "Comparison of aroma volatiles in commercial Merlot and Cabernet sauvignon wines using gas chromatographyolfactometry and gas chromatography-mass spectrometry," Journal of Agriculture and Food Chemistry 54(11), 3990-3996. DOI: 10.1021/jf053278p

Ha, J. H., Lee, D. U., Lee, J. T., Kim, J. S., Yong, C. S., Kim, J. A., Ha, J. S., and Huh, K. (2000). "4-Hydroxybenzaldehyde from Gastrodia elata B1. is active in the antioxidation and GABAergic neuromodulation of the rat brain," Journal of Ethnopharmacology 73(1-2), 329-333. DOI: 10.1016/S0378-8741(00)00313-5

Hsu, Y.-W., Chen, Y.-J., Wu, K.-T., and Chang, S.-T. (2006). “Application of solid phase microextraction technique to the analysis of biogenic volatile organic compounds (in Chinese)," Quarterly Journal of Chinese Forestry 39(2), 279-292. DOI:

10.30064/QJCF.200606.0010

Huang, W., Wu, Y, Zhao, Z., Yi, S., and He, Z. (2016). "Influence of thermal treatment conditions on the release of volatile organic compounds from bamboo," BioResources 11(3), 7296-7304. DOI: 10.15376/biores.11.3.7296-7304

Ibrahim, M. A., Kainulainen, P., and Aflatuni, A. (2001). "Insecticidal, repellent, antimicrobial activity and phytotoxicity of essential oils: With special reference to limonene and its suitability for control of insect pests," Agricultural and Food Science 10(3), 243-259. DOI: 10.23986/afsci.5697

Jayasekara, T. K., Stevenson, P. C., Belmain, S. R., Farman, D. I., and Hall, D. R. (2002). "Identification of methyl salicylate as the principal volatile component in the methanol extract of root bark of Securidaca longepedunculata Fers," Journal of Mass Spectrometry 37, 577-580. DOI: 10.1002/jms.314

Kaunzinger, A., Juchelka, D., and Mosandl A. (1997). "Progress in the authenticity assessment of vanilla. 1. Initiation of authenticity profiles," Journal of Agricultural and Food Chemistry 45(5), 1752-1757. DOI: 10.1021/jf9606971

Klensporf, D., and Henryk, H. J. (2008). "Effect of heat treatment on the flavor of oat flakes," Journal of Cereal Science 48(3), 656-661. DOI: 10.1016/j.jcs.2008.02.005

Kumbhare, V., and Bhargava, A., (2007). "Effect of processing on nutritional value of central Indian bamboo shoots. Part-1," Journal of Food Science and Technology 44(1), 29-31.

Lehtinen, P., and Laakso, S. (2004). "Role of lipid reactions in quality of oat products," Agricultural and Food Science 13, 88-99. DOI: NBN:fi-fe2015090311341

Liese, W. (1987). "Research on bamboo," Wood Science and Technology 21, 189-209. DOI: $10.1007 / \mathrm{BF} 00351391$

Lu, B., Cai, H., Wu, X., Luo, Y., Liu, L., and Zhang, Y. (2011). "Protective effect of bamboo shoot oil on experimental nonbacterial prostatitis in rats," Food Chemistry 124(3), 1017-1023. DOI: 10.1016/j.foodchem.2010.07.066

Lu, C. M. (2001). Cultivation and Management of Bamboo Forests (in Chinese), Taiwan Forestry Research Institute, Taipei, Taiwan.

Luo, Y. J. (2009). Studies of Management Efficiency between Bamboo and Timber - An Illustration of Phyllostachys pubescens and Cunninghamia lanceolata Hook (in Chinese), Master's Thesis, National Chung Hsing University, Taiwan.

Nirmala, C., David, E., and Sharma, M. L. (2007). "Changes in nutrient components 
during ageing of emerging juvenile bamboo shoots," International Journal of Food Sciences and Nutrition 58(8), 612-618. DOI: 10.1080/09637480701359529

Nirmala, C., Sharma, M. L., and David, E. (2008). "A comparative study of nutrient components of freshly harvested, fermented and canned bamboo shoots of Dendrocalamus giganteus Munro," Journal of the America Bamboo Society 21(1), 41-47.

Olivares, A., Navarro, J. L., and Flores, M. (2011). "Effect of fat content on aroma generation during processing of dry fermented sausages," Meat Science 87(3), 264273. DOI: $10.1016 /$ j.meatsci.2010.10.021

Park, E. J., and Jhon, D. Y. (2010). "The antioxidant, angiotensin-converting enzyme inhibition activity, and phenolic compounds of bamboo shoot extracts," LWT - Food Science and Technology 43(4), 655-659. DOI: 10.1016/j.lwt.2009.11.005

Sant'Anna, M. P., Fontes, S. P., Pinto, A. C., and Rezende, C. M. (2007). "Characterization of woody odorant contributors in copaiba oil (Copaifera multijuga Hayne)," Journal of Brazilian Science 18(5), 984-989. DOI: 10.1590/S010350532007000500016

Satya, S., Bal, L. M., Singhal, P., and Naik, S. N. (2010). "Bamboo shoot processing: food quality and safety aspect (a review)," Trends in Food Science 21(4), 181-189. DOI: 10.1016/j.tifs.2009.11.002

Thompson, A., Boland, M., and Singh, H. (2009). Milk Proteins: From Expression to Food, Typeset by Charon Tec Ltd., A Macmillan Company, U.S.A., pp. 431-441.

Tsai, S. W. (2002). The Antibacterial Activities of Various Species of Bamboo Shoots Extracts (in Chinese), Master's Thesis, National Pingtung University of Science and Technology, Taiwan.

Tu, N. T. M., Onishi, Y., Choi, H.-S., Kondo, Y., Bassore, S. M., Ukeda, H., and Sawamura, M. (2002). "Characteristic odor components of Citrus sphaerocarpa Tanaka (Kabosu) cold-pressed peel oil," Journal of Agricultural and Food Chemistry 50(10), 2908-2913. DOI: 10.1021/jf011578a

Wang, H. X., and Ng, T. B. (2003). "Dendrocin, a distinctive antifungal protein from bamboo shoots," Biochemical and Biophysical Research Communications 307(3), 750-755. DOI: 10.1016/S0006-291X(03)01229-4

Wang, L.-F., Lee, J.-Y., Chung, J.-O., Baik, J. H., So, S., and Park, S.-K. (2008). "Discrimination of teas with different degrees of fermentation by SPME-GC analysis of the characteristic volatile flavour compounds," Food Chemistry 109(1), 196-206. DOI: 10.1016/j.foodchem.2007.12.054

Yang, D. S., Lee, K.-S., Jeong, O.-Y., Kim, K.-J., and Kays, S. J. (2008). "Characterization of volatile aroma compounds in cooked black rice," Journal of Agricultural and Food Chemistry 56(1), 235-240. DOI: 10.1021/jf072360c

Yang, X., and Peppard, T. (1994). "Solid-phase microextraction for flavor analysis," Journal of Agricultural and Food Chemistry 42(9), 1925-1930. DOI: 10.1021/jf00045a018

Article submitted: May 18, 2020; Peer review completed: July 13, 2020; Revised version received and accepted: September 20, 2020; Published: September 25, 2020.

DOI: $10.15376 /$ biores.15.4.8744-8755 